\title{
Evolution of Retail Distribution Functions in Omnichannel Environment (Evidence from Bulgarian Retail Sector)
}

\author{
Prof. PhD Violeta Dimitrova \\ University of Economics-Varna, Varna, Bulgaria \\ violeta_dimitrova@ue-varna.bg
}

\begin{abstract}
The evolution of the distribution, as a result of the development of new communication technologies and transformations in consumer behavior, is the subject of extensive academic studies. The purpose of this article is to investigate and summarize the changes in the retail distribution functions in an omnichannel environment in the context of economic and marketing theory. The role of distribution services, wholesale and retail trade is the starting point in the analysis of the added value of the trade sector. The author argues that in order to make sense of changes in the retail distribution functions, it is necessary to look at the buying, selling and exchange functions, marketing and supply chain logistics in an interconnected way. The article is based on the research of authors in the field of distribution and retail economics and marketing. Empirical material from Bulgarian retail sector based on data from National Statistical Institution and Euromonitor illustrates that retailing has started to operate in a omnichannel environment.
\end{abstract}

Keywords: distribution functions, retail product, omnichannel retailing

JEL Code: L81, M21, M31; doi:10.36997/IJUSV-ESS/2019.8.3.101

\section{Introduction}

Experts in field of retail business are unanimous, that this is one of the most dynamic economic sectors (Basker, 2016). This relates particularly to retail trade in Bulgaria. The competitive environment and technological changes in the sector have occurred almost simultaneously during the past 20 years - the processes of concentration through the opening of big commercial sites and the building of retail chains, the changes in the supply chain, the intr oduction of electronic commerce. Presently retail trade faces the challenge of the omnichannel behavior of consumers and the omnichannel environment.

The subject of the present article is the research of the evolution of retail distribution functions and the changes in the supply chain of consumer goods on the example of the retail market in Bulgaria. The article builds on the research of authors such as Basker (2016) and Betankour $(2004,2016)$ and is based on empirical material to illustrate the retail trade processes in Bulgaria based on data from National Statistical Institute of Bulgaria and Euromonitor. The paper is structured in 3 parts. In the first part a review of the literature in field of the retail trade product is made, the transformation of retail distribution services in the consumer goods supply chain is presented in the second section, and in the third part the effects of omnichannel environment on the changes in the retail trade sector in Bulgaria are researched.

\section{Approaches for studying the retail product}

There is vast research of the nature, role and place of modern trade and more specifically of retailing. For example Zentes et al. (2017) point as one of the first complete definition about the role and place of modern commerce that given by Butler (1917), who states that middlemen "... has been forced into existence on the one hand, by the necessities of specialized and large scale industry and, on the other hand, by the necessities of consumers equality specialized in their activities and constantly demanding more and more in the way of services which the distant manufacturer must usually rely upon the middleman to give". In this definition three main distribution functions are visualized - creating an assortment, breaking bulk and bridging space and time.

The selection of approaches for studying the evolution of distribution services, their institutionalization and the structure of the trade sector is determined by the theoretical preparation 
of the author as a researcher. My personal interest in the studying of retail and wholesale trade as an economic sector in Bulgaria dates back 30 years ago and coincides with the beginning of the transition to market economy, when the market competition has emerged after the period of centralized planned economy and monopoly of the state and municipal enterprises in production and trade.

The need of rethinking the place and role of trade as a function of the enterprise and as an economic sector, the dynamics in the processes of restructuring the economy and in particular retail trade, wholesale and international trade have led to the need of applying marketing theory to economic research. Almost all departments at the higher schools of countries in Central and Eastern Europe, specialized in trade as a function and an economic sector, were renamed into marketing ones. Just few universities kept the departments and specialties in economics of trade, retail and wholesale. This demanded the positioning of the economics of commerce not only among the rest of the academic courses, but in the field of scientific research as well. The research and comprehension of changes in the organization of distribution, the supply chain, competition between market participants, the abuse of contractual power in the negotiations between producers and traders inevitably predetermined the study and application not only of the achievements of marketing theory, but also those of economic theory in general .

In one to an ever greater extent specialized market economy, independently whether the distribution is realized by the producer or only is managed by an independent market subject, such as a retailer, and separate of its functions are fulfilled by subcontractors on the basis of outsourcing, the distribution functions of consumer products exist (Zentes et al., 2017). The retail product is a combination between goods and services, which defines the difficulties for its defining and measurement. The share of the goods and the services is different at the different kinds of commercial activity. For example, at the mere intermediary activity and sales representation the service predominates (as well as with agents who do not maintain stock of goods). In the case of full service wholesaler performing logistic operations (maintenance of inventory) - goods predominates.

With a profound feeling of intellectual satisfaction I got acquainted with the publications of authors, among which Betancourt (2004) stands out whith the depth and realization of the essence and the evolution of the retail distribution service. He focuses the necessity of mutual use of marketing and economic theory in research in field of distribution and retailing, and on whose conclusions the present research s grounded. Betancourt (2004) analyses retail transformation in the field of the five main elements of the retail distribution service: location (access to the point of sale), selection and presentation of the assortment, information, delivery and ambience. The applicability of the approach originates from the review of the mentioned "...five distribution services as an essential economic function or output of retail firms or systems..." and "... as fixed factors or inputs in the household production functions of consumers" (Betancourt in Basker, 2016). This approach is aimed at examining of the changes in the relations with the end customers, and is consequently especially useful for studies of the retail product in omnichannel environment.

A little different structure of the traditional retail functions offer Zentes et al. (2017), who also place as first element "creating an assortment", but they separate the "breaking bulk" function, which Betancourt (2004) relates to assurance of product delivery in terms of desire form. They also add as a separate function "product related services", primary and complementary, essential and expected by consumers. The location and delivery are deducted through a function of "bridging space and time", and the information function through "creating demand" in accordance with the academic tradition for its denomination as "informational market decentralization" Zentes et al. (2017).

Besides marketing and logistic functions, the aforementioned authors separate the functions, connected with the exchange "carrying out transactions" and the "efficiency benefits of intermediaries". The last two functions are essential for distribution services and are connected with 
the economic role of the intermediaries. Betancourt (2004) relates a part of the transaction activities to "assurance of product delivery", "as risk-bearing through the acquisition of ownership", provision of credit. With the thesis about intermediaries' efficiency (Rosenbloom, 2010) answers the question, why they keep on existing even in the conditions of the electronic market. It should be emphasized here that retail efficiency is determined by the efficiency of buying, selling and exchange functions. The retail product is also determined by effectiveness and efficiency of the supply chain activities.

The above brings us closer to one of the classic understandings of distribution functions. For example Rosenbloom (2010) derive the flows that take place in the process of product distribution referring to the marketing tradition, marketing channels to be described as a system of eight flows:

1.Product flow

2.Ownership flow

3.Promotion flow

4.Negotiation flow

5.Financing flow

6.Risk flow

7.Ordering flow

8.Payment flow.

The mentioned flows are "another perspective on the same phenomenon" (Zentes et al., 2017). The separate "intermediaries such as retailers, wholesalers, and many different types of agents and brokers" (Rosenbloom et al., 2010) constitute the institutional marketing structure. The channel flows concept is grounded on the classical thesis about commercial activity, specialized in the purchase of goods and/or services and their resale and "the task of channel management becomes essentially one of establishing, coordinating, and monitoring these flows which connect sellers and buyers together" (Rosenbloom et al., 2010).

Internet and the digitalization of trade processes change the relations between market agents, offer new ways of coordinating their behavior, a new specialization and integration of commercial operations. This leads to the requirement to turn to the fundamentals of economic theory and operations management. The necessity of applying a broader theoretical basis for the analysis of the retail product originates from the essence of the exchange, which is at the core of the trade service. When Fayol (1949) defines the enterprise functions he separates the commercial function in three main activities: buying, selling and exchange. Modern approaches, marketing and logistic, redefine and separate the commerce function. In the classical marketing mix, sales are represented with promotional function predominantly, which does not reflect its overall essence in today's competing world. The sales function, whose core is the transaction, the change of the value form and the transfer of the risk, not only the selection and design of distribution channels and marketing logistics. The distribution of income between the participants in the supply chain or the economic efficiency of the intermediaries also does not find an adequate place in the marketing theory. The purchasing functions are subject of the supply chain management theory.

The abovementioned supports Bentacourt's conclusion (Basker et al., 2016) regarding the need of an joint application of the marketing and economic theories during the studying of the retail trade and the economic function of retail firms. He devotes a special place to the theory of transaction costs. Although that the exchange is the core of the contemporary economic, the theoretical conclusions regarding the place of commerce as an intermediary, are comparatively limited, and the focus of economics researches is production. Butler (1917) indicates: "A generation ago manufacturing was the hardest problem in business".

The classical economic theory is grounded on the thesis of labor specialization (Platon, 1981) and the availability of a surplus as a prerequisite for the development of exchange. The theory of marginal utility rethinks the surplus thesis and examines the exchange which stands at the basis of interpersonal communication, as mutually attractive to the parties, not only because they 
consider that they own too much of given items, but because they set a different marginal utility of the possessed scarce goods (Alchian et al., 1983). The price is fixed somewhere in between the different initial marginal assessments of the trading parties. Commerce moves each individual along the curve of his marginal utility. The buyer moves downwards along his curve and the seller upwards. Both parties win. Each of them sets a higher utility to that which he receives, in comparison to that, which he gives (Alchian et al., 1983).

Middlemen are absent in the basic part of the market models. The expenses for the exchange, the so called transaction costs - connected with the search of the potential partners, negotiations, establishing of a contact, preparation and conclusion of the transaction, taking of risk of non-fulfillment of the transaction conditions, etc. are not a subject of research in neoclassical theory. The costs for getting information are absent. It is assumed, that individuals possess the whole information about the transaction. The component connected with the nature of cooperation and coordination of the activities of the participants in the exchange is also missing. The concept of power is ignored as well. These limitations of neoclassical theory try to overcome the institutional theory, transaction costs theory, contract theory, games theory, which have constructed a variety of models, describing the behavior of market participants with taking into account of definite factors. The fundamentals of research in field of transaction costs most economists find in the historical article of Couse (1937) about the nature of the firm, in which he asks and answers the question "...why a firm emerges at all in a specialized exchange economy". The price mechanism is replaced by the firm, because its usage is connected with costs.

In contrast to the neoclassical economic theory, which puts at the center of research the product and consumer attitude towards them, Commons (1932), one of the first institutional economists, directs his theoretical analyses towards the transaction. He stresses, that stable are those economic theories, which consider the transaction and the effective rules, the problems of the organization and the ways of coordination of activities. The thesis, that the transaction should be the basic analysis unit supports Williamson (2002). He underlines that in the transaction costs theory the problems of law, economics and organization are interrelated.

In addition to the transaction costs theory the place of the contract theory should be pointed as well. In the light of the contract theory Williamson (2002) examines the vertical limitations in product distribution. For example, when the producer is in a stronger position during negotiations with trade companies (he possesses a well-established trade mark, works with many retailers and wholesalers, invests in promotions and advertising, gives guarantees to the end customers), often the transactions with the intermediaries include vertical restrictions such as markets (customers and/or territories) and services. Vertical market restrictions have the aim to introduce order in the transaction, where the interests of the system and those of the separate parties are in conflict - for example the limitations for resale imposed on the franchisee in a franchising contract (Bachvarova, 2015).

The changes in communication technologies alter the society, the relations between people and the market agents, and in that way the exchange and commerce, its institutional structure, the research of which requires an integrated approach. "The answer can be found in basic economics" (Rosenbloom, 2010). This originates from the necessity of defining the intermediaries' efficiency, at the basis of which lays the proper defining of the effect of the retail activity and the costs for its realization, which predestines the actuality of the problem of defining the distribution functions.

\section{Omnichannel consumer behavior and retail product}

The analysing of the transformation in retail distribution services is connected with the studying the changes in the exchange and consequently of the whole business eco system. This imposes to obtain ideas from the classics due to a need of an integrated multidisciplinary approach. A century ago Butler (1918) studied the changes in commercial relations in the context of the 
history of international trade and the problems of „complicated trade relations of modern commerce" as a result of the industrial revolution and the introduction of modern production marketing. In the era of new information and communication technologies development Butler's (1918) thesis about commerce with goods, that consumers demand more and more from the viewpoint of distribution services, is still actual.

In traditional trade, with the exception of marketing communications, the distribution services are offered together with the product sold. In electronic trade, especially at the offering of the so called soft products, each of these distribution services can be performed electronically, including the payment and receiving of the product. In the same way, these services can be assigned to external contractors and usually as an economic activity they are related to the services of the information society Betancourt (2004). When the web hosting companies assume distribution functions, the role of retailing as a economic sector is redefined. The provision of augmenting reality also provides space for the specialization of new intermediaries. Betancourt (2004) studies the possibility of providing the distribution services at a minimum cost as "essential differences between online and offline channel", since Internet retailing basically eliminates all storage costs at the point of sales.

E-retailing allows “... separability of production, distribution and consumption of all distribution services across space and time" (Betancourt et al., 2016). The research is based on the fundamental thesis of Betancourt (2004) about five groups of distribution services, as a product of retailing: assortment, accessibility of location, assurance of product delivery, information and ambiance. The studying of this separability gives reason to the authors to define two types of separability - I and II. Type I separability is available, when the production and distribution expenses "are clearly separable in a non-arbitrary fashion, usually identified as cost of goods sold". "When online settings generate separability of production, distribution and consumption of all these distribution services in space and time..."(Betancourt et al., 2016) type II separability is available. As type I is clearly observable in the distribution of goods and some services as a core product, the merit of the authors is in the grounding of type II separability.

Consequently, on the one hand the omnichannel consumer behavior imposes the change in the approaches for its studying as result of the contemporary complex social and cultural world and does not support an orderly and rational explanation of our reality and people's behavior (Peteva, 2018). On the other hand, omnichannel consumer behavior demands from the participants in distribution to give customers an opportunity to use distribution services through all available and known distribution channels, which they treat with confidence, at each of the stages of the buying process, the purchase itself and the activities after it.

Online and offline (bricks-and-mortar) retailing are no longer viewed as separate channels through which the goods and services reach different groups of customers. Broadly quoted are the summaries of Verhoev et al. (2015) regarding the essence of omnichannel retailing and the differences with multichannel retailing: "Compared to the multichannel phase, omnichannel thus involve more channels. An important additional change is that the different channels become blurred as natural borders between channels begin to disappear." Omnichannel environment changes the institutional structure of intermediaries. The elements of the distribution services can be combined in new ways and to be provided by new market participants. Online retailing companies enter offline retailing and vice versa, they use different forms of joint activity, new retail formats are created and offered. For example, the "the just walk out" technology, which combines unique assortment selection, supply of fast turnover goods and fresh foods, alongside with virtual services (deep learning algorithms, sensor fusion) in a physical space. Widespread are so-called pop-up shops, temporary outlets used by e-retailers.

In turn the big traditional offline retailers invest to an even larger extent in information technologies - automation, artificial intellect, robotization, IoT, Voice Assistants, etc. Some experts 
(Newman, 2018) writes, that in a certain time the big retailers will be selling technology to other retailers in addition to consumer products.

It is necessary to emphasize, that new technologies not only change the way of delivering of the five elements of the retail product, but they restructure the exchange on the purchases side. Purchases are a fundamental part of the production function of middlemen, including retailers. Internet, the blockchain technology, the decentralized archive, on which cryptocurrencies are based, the so called "smart" contracts alter the commercial milieu, the way of communication between market agents, the transactions conclusion, verification, saving and tracking, and thus create a new business environment. In the beginning of the last century Butler (1917) pointed, that in marketing: "There is only human element, and no one has yet devised a workable plan to harness human nature and make it act in definitely predetermined ways".

Presently technologies such as mentioned above redefine the division of labor between the market agents - producers, traders, consumers, financial and other intermediaries, and in the trade sector as well, the connection between retail and wholesale. Blockchain technology builds up mainly in the field of transaction, but also in the supply chain - tracing the origin of goods. Through the provision of digital identification (digital ID), the chain of database blocks saves the product information within the life cycle - from the origin to the retail store. This helps customers in the searching of the most suitable form of product delivery. The blockchain technology offers an opportunity for access to and sharing of information, participation in the verification of transactions.

And, as Rosenloom (2010) points, with the development of new information technologies the so called disintermediation paradigm, "that of eliminating middlemen from channels of distribution" gains popularity again. On grounds of the theory of transaction costs in 1987 Malone (1987) formulates the hypothesis of the electronic market, that with the development of ICT the companies to an even larger extent will use the market as a coordination in comparison to the hierarchy. He examines that as a result of decrease of management costs of market transactions and a shift in key factor determining coordination structure: asset specificity and complexity of product description (Malone, 1987).

Although the growth of electronic retail sales, which facilitates the direct trade between producers and final consumers, many middlemen build successful electronic, multichannel and omnichannel business. Rosenbloom (2010) asks the question: "Why do so many middlemen continue to exist even in the face of the awesome power of Internet-based electronic commerce?" The answer is connected with the efficiency of trade intermediaries as a main criteria for their existence, and for this purpose all trade effects and expenditures have to be compared.

\section{Bulgarian retail sector in omnichannel environment}

The change in the institutional structure of retail sector is the result of changes in the way distribution services are provided. The innovative waves in retailing -1.0 (self service, retail chains, franchise et al.), 2.0 (big box retailers) , 3.0 (e-commerce) and 4.0 (multichannel and omnichannel retailing) (Desai et al., 2016) have emerged within a century in the developed countries, but in Bulgaria they have taken place one after another within very short time periods and with overlapping.

The first step in the transition period was the creation of a competitive market environment. After 1990, in just 10 years, the changes in the properties of trade firms were achieved as a result of the processes of demonopoliziation of state retail and wholesale trade enterprises (including retail trade chains), the restitution of a part of trade assets, the privatization, the development of private entrepreneurship. The indicated processes allowed the formation of a competitive environment in the trade sector. By 1999 the private retail trade chains are small, basically local and foreign chains have not entered the market. The national cooperative retail chain solely maintains its relative integrity, but its technological renovation is still at its beginning. 


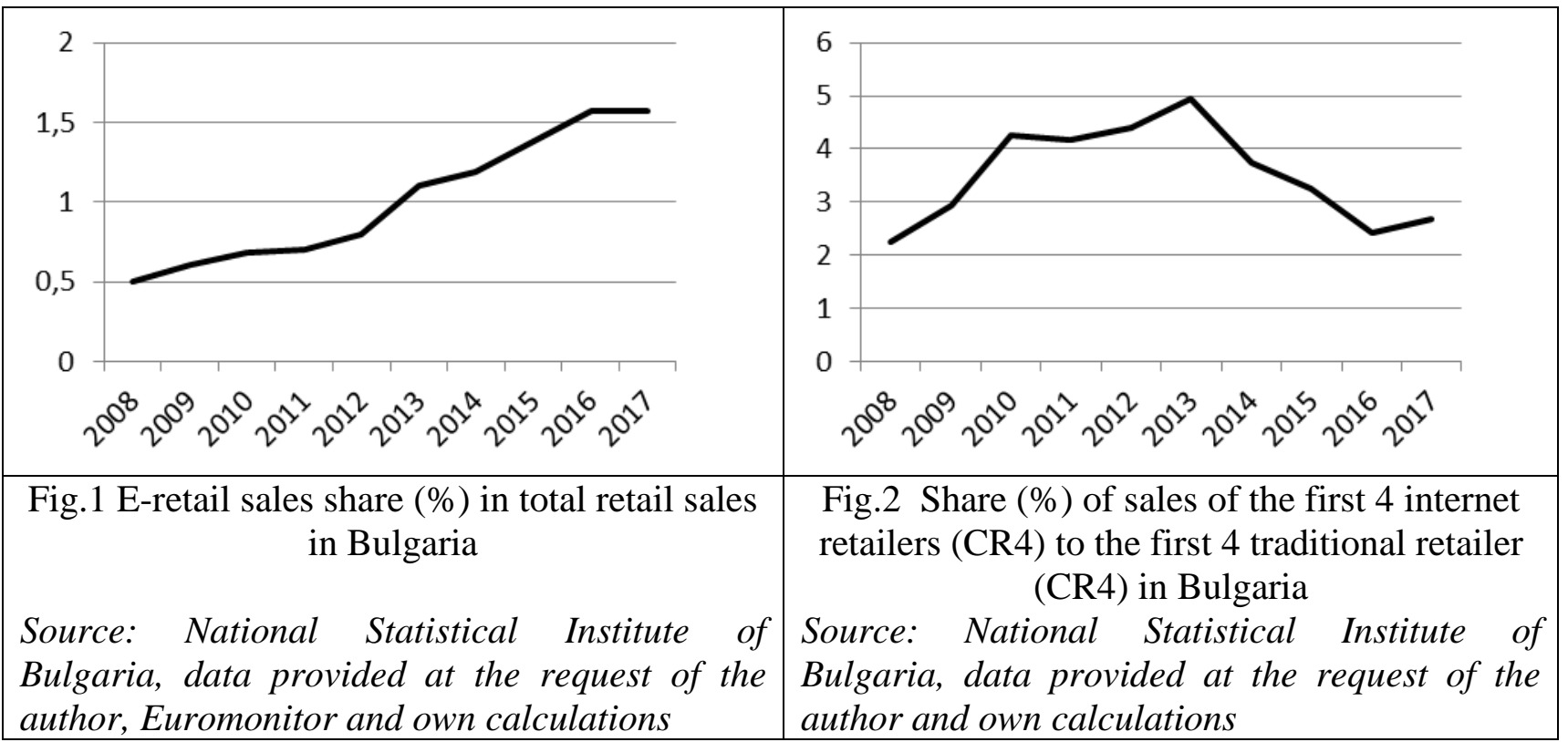

Currently retail chains continue to increase their market share, to gain to an even larger extent the control over the supply chain. They fulfill functions, traditional for producers and wholesale traders, and thus reorganize their own operations and those of the suppliers. The retail chains perform more frequently activities connected with the product design, the purchase of raw materials, distribution, including foreign trade activity. The share of the products with an own retail brands is growing. The intangible assets as: concessions, patents, licenses, trademarks, software products and other similar rights and asset have greatest share in the intellectual capital in the trade sector in Bulgaria (Nikolova, 2019).

The concentration in electronic trade in Bulgaria is bigger than in the traditional one. The market share of the four companies with the highest sales volume (CR4 index) reaches $16.2 \%$ in 2018 according to Euromonitor for retail trade as a whole, but CR4 in an internet retailing is $38,1 \%$ for the same year.

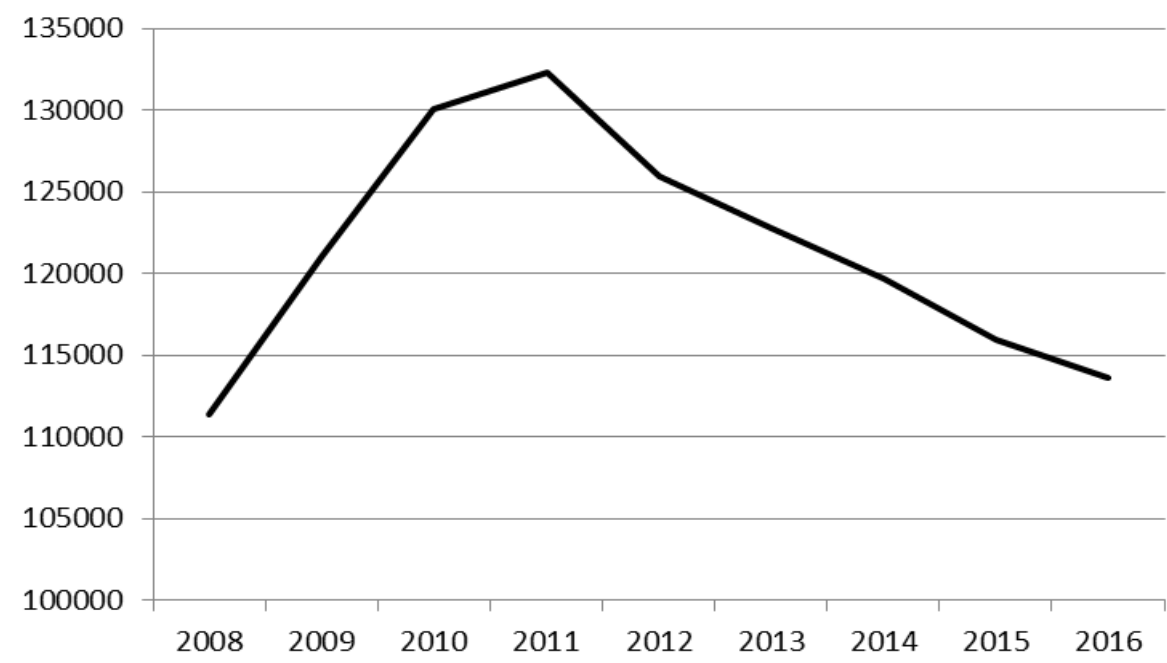

Fig. 3 Number of ofline retail outlets in Bulgaria Source: National Statistical Institute of Bulgaria 
Big retail chains, originally created as offline retailers, are increasingly using electronic channels at different stages of sales. According to NSI and Euromonitor, the share of pure internet retail sales to total retail sales increased from $0.5 \%$ in 2008 to $1.57 \%$ in 2017 (fig. 1). However, it should be noted that pure retail distribution channels cannot be statistically captured and registered. In order to account sales as electronic, the prerequisite is that the order is made electronically (by desktop or laptop computer, tablet, mobile phone, smartphone). But the client can learn about a product from social networks, get a consultation in a physical outlet, place an order electronically and receive it in the store (for example "click and collect" system). Customers can receive any of the retail distribution services, which are part of a single channel, either online or offline.

Figure 2 represents the relative share of electronic sales of the four largest companies in Bulgaria compared to the volume of sales of the four largest traditional retailers, which shows a decrease. This trend is against the backdrop of an increase in internet sales in volume, as well as a growing share of Internet users. According to National Statistical Institute data the value of sales through online stores, web applications or automated data exchange increased from 1090 million in 2008 to BGN 7,167 million in 2016.

As shown in Figure 3 the number of physical retail outlets has decreased since 2011, but the average sales volume per retail outlet at comparable prices $(2008=100 \%)$ has increased in 2016 , reaching 299 million BGN average per outlet in 2016 (fig.4 ). It should be noted that in 2016 total retail sales at 2008 prices reached sales in 2008. Among the top 10 retailers by e-sales only 2 retailers have no physical retail outlets according Euromonitor data base.

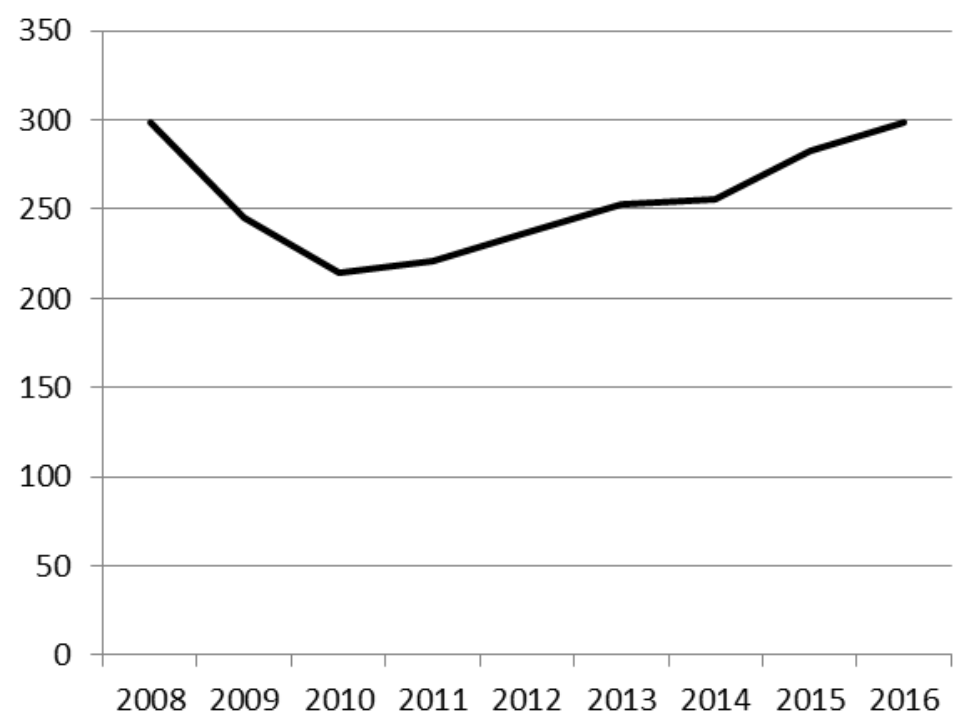

Fig. 4 Average retail sales in millions BGN per outlet in Bulgaria

Evidence of an increase in electronic data exchange in the supply chain is the share of businesses purchasing online goods and services, which increased from $5.1 \%$ in 2008 to $17 \%$ in 2018. The processes are carried out in parallel with the significant increase in revenue from the information services sector (J 63 Information services - data processing, hosting, search web portals and other according NACE, Statistical classification of economic activities in the European Community). The number of enterprises in the information and communication sector for the time period 2008-2017 increased by $112 \%$ compared to the wholesale and retail trade sector, where the number of enterprises increased by $12.41 \%$ for the same period. Value added at the cost factor in 
the information and communication sector increased by $69.73 \%$ and in trade - by $50.72 \%$. Revenue of the firms in advertising and market research sector is growing rapidly.

\section{Conclusion}

A brief descriptive analysis of the retail sector in Bulgaria shows that it is difficult to report a pure online or offline retail marketing channel. The share of electronic tools and technologies is growing as part of a whole omnichannel marketing channels. Also, the application of electronic data interchange in the supply chain of retail firms is expanding, which affects the efficiency of the trade processes carried out. The results support the thesis that processes to create an omnichannel environment, in which the trade sector operates, have begun.

With the introduction of the new information and communication technologies, the dynamics and complexity of business processes is growing, which demands integrated approaches for resolving the complex business tasks. As IT services are no longer a subsidiary function to the business processes, but their integral element, so the electronic and internet commerce are turning into an integrating part of the business processes. The new realities demand complex approaches, which is a prerequisite for integration of knowledge from different fields and an even larger cooperation between scientists and researchers.

An analysis of the evolution of retailing as a result of omnichannel consumer behavior, digitalization, blockchain and smart contracts, can be made by considering the all retail distribution functions, incl. buying, selling and transactions.

\section{References}

1. Alchian, A. and Allen, W. (1983) Exchange and Production. Competition, Coordination and Control. California, USA: Wadsworth Publishing Company, p.45-47.

2. Bachvarova, M. (2015) Specifichni nenaimenuvani targovski dogovori - insitut na dogovornoto parvo. Varna, Bulgaria: University Publishing Nauka i ikonomika, pp.184-242.

3. Basker, E. (2016) Handbook on the Economics and Distribution. Massachusetts: Edward Elgar Publishing Limited, p.1 pp.74-79.

4. Betancourt, R. (2004) The Economics of Retailing and Distribution. Cheltenham, UK and Northampton, MA, USA: Edward Elgar, pp.17-20, p.102.

5. Betancourt, R., Chocarro, R., Cortinas, M., Elorz, M., Mugica, J. (2016) Channel Choice in the 21st Century: The Hidden Role of Distribution Services. Journal of Interactive Marketing, 33, pp.1-12.

6. Butler, R. (1918) Marketing Methods. New York, USA: Alexander Hamilton Institute, [Online] Available from:https://archive.org/details/marketingmethods05butluoft/page/14 [Accessed 18/10/2019], pp.14-16.

7. Commons, J. (1932) The Problem of Correlating Law, Economics, and Ethics, Wisconsin Law Review, 8, pp. 3-26.

8. Couse, R. (1937) The Nature of the Firm. Economica, New Series, Vol. 4, No. 16, Nov., pp. 388-390.

9. Desai, P., Potia, A., Salserg, B. (2016) Retail 4.0:The Future of Retail Grocery in a Digital World, McKinsey\&Company, [Online] Available from: https://www.sipotra.it/wpcontent/uploads/2017/06/The-future-of-retail-grocery-in-a-digital-world.pdf,

[Accessed 13/11/2019], pp.3-6.

10. Euromonitor, [Online] Available from Passport: https://www.portal.euromonitor. com/portal/account/login, [Accessed 13/11/2019]. 
11. Fayol, H. (1949) General and Industrial Management, London: Sir Isaac Pitman\&Sons, (translated by Constance Storrs), p.3.

12. Malone, T., Yates, J., Benjamin, R. (1987) Electronic Markets and Electronic Hierarchies, Communications of the ACM 30(6), June, p. 489.

13. National Statistical Institute of Bulgaria, [Online] Available from: https://www.nsi.bg/en, [Accessed 13/11/2019].

14. Newman, D. (2018) Top 7 Digital Transformation Trends from NRF 2018 (National Retail Foundation), [Online] Available from: https://www.forbes.com/sites/daniel newman/2018/02/14/top-7-digital-transformation-trends-from-nrf-2018/\#2e40455e6aff, [Accessed 13/11/2019]

15. Nikolova, I. (2019) Manifestation of Intellectual Capital in Trade During Period 2008-2018, Economic Alternatives, Issue 3, [Online] Available from: https://www.unwe.bg/uploads/Alternatives/4_Nikolova_EA_en_i3_2019.pdf, [Accessed 13/11/2019], pp. 382.

16. Peteva, V. (2018) Strategicheski aspecti na potrebitelskoto povedenie i osnovni paradigmi v negovoto izuchavane. Izvestia Journal of the Union of Scientists - Varna, Economic Sciences Series, Varna: Union of Scientists - Varna. volume 7, issue 1, p.81.

17. Platon. (1981) Darjavata. Sofia, Bulgaria: Nauka I izkustvo (translated by prof. Milev, A.), pp.70-73.

18. Rosenbloom, B. (2010), Six Classic Distribution Paradigms for Global Marketing Channel Strategy, Symphonya Emerging Issues in Management, n. 1, [Online] available from:https://pdfs.semanticscholar.org/30f3/b64866710593e6633d68e4e18509643f32e7.pdf , [Accessed 20/10/2019], pp.7-11. Vernoef, P., Kannan, P., Inman, J. (2015) From Multi-Channel Retailing to Omni-Channel Retailing. Journal of Retailing, March , p.2, [Online] Available from: https://www.researchgate.net/publication/274404553_From_MultiChannel_Retailing_to_Omni-Channel_Retailing [Accessed 21/10/2019]

19. Williamson, O. (2002) The Theory of the Firm as Governance Structure: From Choice to Contract. Journal of Economic Perspectives, Volume 16, Number 3, Summer, pp. 175-179.

20. Zentes, J., Morschett, D., Klein, H. (2017) Strategic Retail Management. $3^{\text {rd }}$ Edition. Germany: Springer Gabler, pp.3-12. 